\title{
POTENSI AGROFORESTRI DI DESA MARA SATU KABUPATEN BULUNGAN PROVINSI KALIMANTAN UTARA
}

\author{
Marlan Usmani Putra ${ }^{1,2}$, Rujehan², Mustofa Agung Sardjono², Paulus Matius², \\ Ahyauddin ${ }^{3}$ \\ ${ }^{1}$ Fakultas Pertanian Universitas Kaltara Jalan Sengkawit Tanjung Selor Hilir Kabupaten \\ Bulungan Provinsi Kalimantan Utara 77212 \\ ${ }^{2}$ Fakultas Kehutanan Universitas Mulawarman Samarinda Provinsi Kalimantan Timur \\ ${ }^{3}$ Fakultas Kehutanan Universitas Jambi Kampus Pinang Masak Unja Mendalo, Jln Raya \\ Jambi - Ma. Bulian KM 15, Jambi.
}

E-Mail: usmani.marlan@gmail.com

\begin{abstract}
ABSTRAK
Potensi Agroforestri di Desa Mara Satu Kabupaten Bulungan Provinsi Kalimantan Utara. Agroforestri tradisional yang berkembang dari budaya lokal memiliki peran penting sebagai sumber pendapatan rumah tangga petani di Desa Mara Satu. Pendapatan merupakan indikator ekonomi petani karena besarnya pendapatan akan menentukan pemenuhan kebutuhan hidupnya, tetapi pendapatan juga ditentukan oleh nilai ekonomi dari komoditi atau produk agroforestri yang dihasilkan oleh petani. Potensi Agroforestri dapat dilihat dari dua aspek, yaitu potensi vegetasi penyusun agroforestri dan potensi ekonomi komoditi agroforestri. untuk potensi vegetasi penyusun agroforesti dengan melihat hasil hutan kayu dan hasil hutan non kayu, sedangkan potensi ekonomi dilihat dari nilai ekonomi dari produk agroforestri yang dihasilkan dari sistem agroforestri yang ada. Penelitian ini dilaksanakan di Desa Mara Satu Kecamatan Tanjung Palas Barat Kabupaten Bulungan Provinsi Kalimantan Utara. Metodologi yang digunakan adalah metode purposive sampling yaitu pengambilan sampel secara sengaja sedangakan penentuan jumlah sampel ditentukan berdasarkan teknik Slovin. Analisis data menggunakan deskriptif kuantitatif dan dimuat dalam bentuk tabel. Berdasarkan hasil penelitian dapat diketahui bahwa Volume total (potensi) tanaman agroforestri responden Desa Mara Satu adalah 797,18 $\mathrm{m}^{3}$ dengan Volume tegakan paling besar adalah tanaman Durian (Durio zibethinus) sebesar $270.34 \mathrm{~m}^{3}$. Potensi tanaman obat Desa Mara Satu memiliki total nilai ekonomi sebesar Rp. 177.099.000,- per tahun dengan potensi yang paling besar adalah jahe merah (Zingiber officinale Linn. var. rubrum) yaitu sebesar Rp. 81.600.000,- per tahun. Total nilai ekonomi produk tanaman agroforestri dari 37 responden petani Desa Mara Satu adalah sebesar Rp. 3.385.889.000,- per tahun.
\end{abstract}

Kata kunci : Desa Mara Satu, Hasil hutan kayu, Hasil hutan non kayu, Nilai ekonomi dan Potensi agroforestri.

\begin{abstract}
Potential of Agroforestry in Mara Satu Village, Bulungan District, Province of North Kalimantan. Traditional agroforestry that developed from local culture has an important role as a source of income for farm households in the village of Mara Satu. Income is an economic indicator of farmers because the amount of income will determine the fulfillment of their needs, but income is also determined by the economic value of the commodity or agroforestry products produced by farmers. The potential of agroforestry can be seen from two aspects, namely the potential of vegetation making up agroforestry and the economic potential of agroforestry commodities. for the potential of vegetation making up agroforestry by looking at timber forest products and non-timber forest products, while the economic potential is seen from the economic value of agroforestry products produced from the existing agroforestry system. This research was conducted in Mara Satu Village, Tanjung Palas Barat District, Bulungan Regency, North Kalimantan Province. The methodology used is purposive sampling method that is deliberate sampling while the determination of the number of samples is determined based on the Slovin technique. Analysis of data using quantitative descriptive and loaded in tabular form. Based on the results of the study it can be seen that the total volume
\end{abstract}


(potential) of agroforestry plants of the respondents of Mara Satu Village is $797.18 \mathrm{~m} 3$ with the highest volume of stands is Durian (Durio zibethinus) of $270.34 \mathrm{m3}$. The potential of medicinal plants in Mara Satu Village has a total economic value of Rp. 177,099,000 per year with the greatest potential is red ginger (Zingiber officinale Linn. Var. Rubrum), which is Rp. 81,600,000 per year. The total economic value of agroforestry products from 37 respondents from Mara Satu Village is Rp. 3,385,889,000 per year.

Key words : Mara Satu Village, Timber Forest Products, Non-Timber Forest Products, Economic Value and Agroforestry Potential.

\section{PENDAHULUAN}

Agroforestri merupakan kegiatan penggunaan lahan yang bertujuan untuk mempertahankan atau meningkatkan hasil total secara lestari, dengan cara mengkombinasikan tanaman berkayu (pohon) dengan tanaman pangan atau tanaman pakan ternak pada sebidang lahan yang sama, baik secara bersamaan atau secara bergantian, dengan menggunakan praktek-praktek pola pengelolaan yang sesuai dengan kondisi ekologi, ekonomi, sosial dan budaya setempat. Agroforestri memiliki banyak manfaat untuk sumber pendapatan masyarakat sekitar hutan, dengan tidak hanya memanfaatkan dari hutan berupa hasil hutan kayu dan hasil hutan non kayu saja tetapi masyarakat juga dapat memanfaatkan hasil dari tanaman pertanian. Nair (1993) menambahkan bahwa agroforestri merupakan sistem pengelolaan lahan yang berasaskan kelestarian dan sesuai dengan keadaan sosial budaya penduduk setempat.

Salah satu daerah di Kabupaten Bulungan yang sebagian besar sistem pertaniannya menerapkan sistem agroforestri adalah masyarakat desa Mara Satu. Potensi jenis komoditi yang dikembangkan oleh masyarakat Desa Mara Satu dalam sistem agroforestri sangat beragam.

Potensi Agroforestri dapat dilihat dari dua aspek, yaitu potensi tegakan penyusun agroforestri dan potensi ekonomi komoditi agroforestri. Untuk potensi tegakan penyusun agroforesti yang dilihat adalah hasil hutan kayu dan hasil hutan non kayu, sedangkan potensi ekonomi yang dilihat adalah nilai ekonomi dari produk agroforestri yang dihasilkan dari sistem agroforestri yang ada.

Sistem Agroforestri di Desa Mara Satu sebagian besar mengikuti pola tradisional. Alasan para petani menerapkan pola agroforestri tersebut sudah menjadi budaya lokal yang turun temurun dari nenek moyang terdahulu. Praktek agroforestri tradisional berawal dari tanaman yang tumbuh spontan dari biji-biji yang dibuang dilahan pertanian atau mempertahankan dan memelihara pohon-pohon permudaan yang sudah ada kemudian dikembangkan dengan pembudidayaan tanaman dan berlangsung secara terus menerus.

Agroforestri tradisional yang berkembang dari budaya lokal ini memiliki peran penting sebagai sumber pendapatan rumah tangga petani di Desa Mara Satu. Pendapatan merupakan indikator ekonomi petani karena besarnya pendapatan akan menentukan pemenuhan kebutuhan hidupnya, tetapi pendapatan petani juga ditentukan oleh nilai ekonomi dari komoditi atau produk agroforestri yang dihasilkan oleh petani.

Pemahaman masyarakat terhadap pola agroforestri masih sangat terbatas. Masyarakat atau petani masih sangat tergantung pada hasil komoditi dari sistem agroforestri, namun masyarakat belum mengetahui sejauh mana hasil produksi agroforestri memberikan kontribusi terhadap pendapatan rumah tangga. Dalam sistem agroforestri penyumbang pendapatan petani bisa diperoleh dari hasil hutan kayu dan non 
kayu. Oleh karena itu, perlu dilakukan penelitian tentang Potensi Vegetasi dan nilai ekonomi dari produk hasil agroforestri di Desa Mara Satu Kabuten Bulungan Provinsi Kalimantan Utara.

\section{METODA PENELITIAN}

\subsection{Tempat dan Waktu}

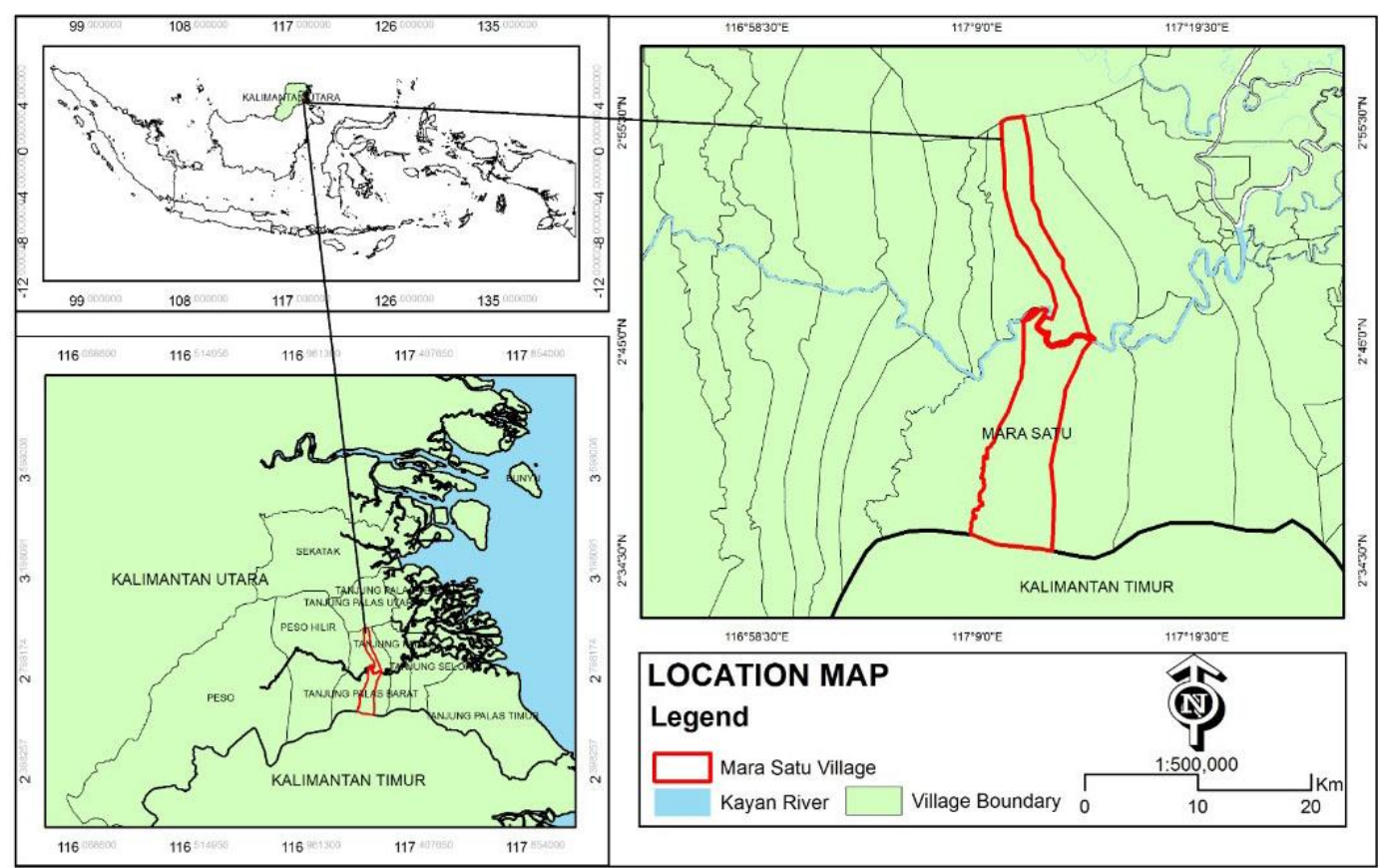

Gambar 1. Peta Lokasi Penelitian Desa Mara Satu

\subsection{Prosedur Penelitian}

\subsubsection{Pengambilan sampel}

Penentuan sampel atau responden dilakukan dengan metode purposive sampling yaitu pengambilan sampel secara sengaja terhadap Penduduk Desa Mara Satu
Penelitian ini dilaksanakan di Desa Mara Satu Kecamatan Tanjung Palas Barat Kabupaten Bulungan. Desa Mara Satu memiliki luas 343,87 $\mathrm{Km}^{2}$ dengan ketinggian tempat \pm 300 $\mathrm{m}$ dpl. Penelitian ini dilaksanakan selama 2 (dua) bulan dari Mei s/d Juli 2019. 
reponden yang dipilih secara purposive sampling berdasarkan keikutsertaan masyarakat dalam pengembangan sistem agroforestri sehingga diperoleh jumlah responden sebanyak 37 responden.

Penentuan sampel pohon untuk memperoleh data potensi tegakan (Hasil Hutan Kayu) diperoleh dengan membuat 3 plot contoh berbentuk lingkaran pada masingmasing lahan responden dengan jari-jari 17,8 meter dan luas masing-masing plot adalah 0,1 ha. Lalu dihitung jumlah pohon dalam plot dan diukur dimeter setinggi dada dan tinggi bebas cabang pohonnya.

\subsubsection{Teknik Pengambilan Data dan} Jenis Data

Pengambilan data dilakukan secara langsung dilapangan sebagai berikut :

a. Inventarisasi tanaman hutan yang dibudidayakan masyarakat di Desa Mara Satu.

b. Melakukan observasi dan analisis pengelolaan tanaman agroforestri yang ada di lapangan.

c. Wawancara dan diskusi dengan menggunakan kuisioner terhadap para pelaku yang mengelola tanaman agroforestri.

d. Keseluruhan data selanjutnya ditabulasi sesuai kebutuhan sebelum dilakukan pengolahan dan analisis data. Jenis Data yang diperoleh dari setiap responden meliputi :

a) Identifikasi diri responden.

b) Luas Lahan yang dimiliki.

c) Metode penjualan hasil pemanenan dan harga jualnya.

d) Potensi tanaman agroforestri yang dibudidayakan meliputi jenis, diameter, tinggi pohon, luas bidang dasar dan volume tegakkan.

\subsubsection{Potensi Tanaman Agroforestri}

Penaksiran potensi kayu tanaman agroforestri dilakukan dengan cara menghitung potensi tanaman agroforestri yang dimiliki oleh setiap sampel responden pada desa/wilayah kajian. Dari data dari hasil inventarisasi kayu tanaman agroforestri kemudian dapat dihitung parameterparemeter tegakkannya yang meliputi jenis pohon, jumlah pohon, luas bidang dasar (Lbds), dan volume per satuan luas.

Lbds dapat dihitung dengan rumus sebagai berikut :

$$
\text { Lbds }=0,25 \times \pi \times D i^{2}
$$

Dimana : Lbds $=$ Luas bidang dasar tegakan $\left(\mathrm{m}^{2}\right)$

Di = Diameter batang (tinggi pengukuran 1,3 m) untuk pohon jenis i $(\mathrm{m})$

Penghitungan volume tegakan berdiri tanaman agroforestri dapat dihitung dengan rumus berikut :

$$
V i=L b d s \times t i \times f i
$$




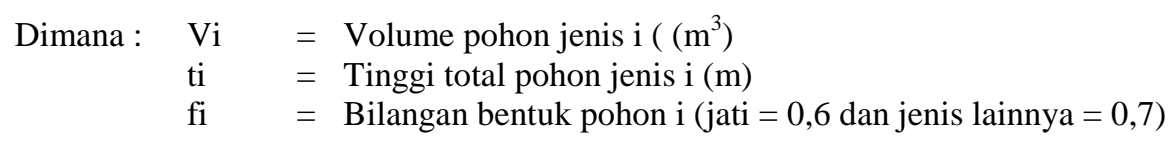

Data yang diperoleh disusun dan diolah dalam bentuk tabulasi. Analisis data dilakukan secara deskriptif berdasarkan tabulasi yang didapat.

2.2.4. Nilai Ekonomi Produk Agroforestri Data ekonomi yang diperoleh dari hasil pengamatan dilapangan melalui wawancara dan kuisioner kemudian dianalisis secara kuantitatif. Nilai produk agroforestri untuk setiap jenis per tahun yang diperoleh setiap responden (petani) dihitung dengan cara sebagai berikut :

a. Harga barang hasil hutan (manfaat langsung/tangible) yang diperoleh dianalisis dengan metode pendekatan pasar.

b. Menghitung nilai rata-rata jumlah barang yang diambil per responden per jenis dengan formulasi sebagai berikut :

$$
\mathrm{X}=\frac{z 1+x 2 m x n}{n}
$$

Dimana : $\mathrm{X}=$ rata-rata jumlah produk agroforestri yang diambil $(\mathrm{RJ})$

$\mathrm{X} 1=$ Jumlah barang yang diambil responden

$\mathrm{n}=$ Jumlah pengambilan per jenis barang

c. Menghitung total

pengambilan per unit barang

per tahun, diformulasikan sebagai berikut :

$$
T P=R J \times F P x J P
$$

$$
\begin{aligned}
& \text { Dimana: } \mathrm{TP}=\text { Total Pengambilan Produk Agroforestri per tahun } \\
& \text { RJ }=\text { rata-rata jumlah produk agroforestri yang diambil } \\
& \text { FP }=\text { Frekuensi pengambilan produk agroforestri per tahun } \\
& \text { JP }=\text { Jumlah pengambilan per jenis produk agroforestri per tahun }
\end{aligned}
$$

d. Menghitung nilai ekonomi barang per tahun, produk agroforestri per jenis diformulasikan dengan :

$$
N H=T P x H H
$$
Dimana: $\quad \mathrm{NH}=$ Nilai Produk Agroforestri per jenis per tahun
$\mathrm{TP}=$ Total pengambilan produk agroforestri per unit per tahun
$\mathrm{HH}=$ Harga produk agroforestri per jenis

e. Menghitung persentase nilai ekonomi dengan cara sebagai berikut :

$$
\% \mathrm{NE}=\frac{\mathrm{NE} i}{\sum N E} \times 100 \%
$$


Dimana : $\% \mathrm{NE}=$ Persentase Nilai ekonomi produk Agroforestri

$\mathrm{NE} i=$ Nilai ekonomi produk agroforestri per jenis

$\sum N E=$ Jumlah total nilai ekonomi dari seluruh produk agroforestri

\section{HASIL PENELITIAN DAN PEMBAHASAN}

\subsection{Potensi Agroforestri}

\subsubsection{Potensi Hasil Hutan Kayu}

Penaksiran potensi kayu tanaman agroforestri dilakukan perhitungan potensi tanaman agroforestri yang dimiliki oleh setiap sampel responden pada desa/wilayah kajian. Data dari hasil inventarisasi kayu tanaman agroforestri dapat dilihat di Tabel 1, kemudian dapat dihitung parameter-parameter tegakkannya yang meliputi jenis pohon, jumlah pohon, luas bidang dasar (Lbds), dan volume persatuan luas.

Tabel 1. Jenis Tanaman Berkayu Pada Lahan Agroforestri di Desa Mara Satu

\begin{tabular}{|c|c|c|c|c|c|c|c|c|}
\hline \multirow{2}{*}{ No. } & Jenis & Jumlah & $\mathrm{T}$ & TBC & K & $\mathrm{D}$ & LBDS & V \\
\hline & Tanaman & (N/0,1 ha) & (m) & (m) & (m) & (m) & $(\mathrm{m} 2)$ & (m3) \\
\hline 1 & Durian (Durio zibethinus) & 224 & $2,232.69$ & 733.08 & 324.39 & 103.22 & 38.27 & 270.34 \\
\hline 2 & Elai (Durio kutejensis) & 157 & $1,219.10$ & 427.07 & 134.44 & 42.78 & 9.44 & 52.44 \\
\hline 3 & Kuweni (Mangifera odorata) & 121 & 924.85 & 542.65 & 141.90 & 45.15 & 13.33 & 72.22 \\
\hline 4 & Duku (Lansium domesticum) & 125 & $1,788.92$ & 967.03 & 237.58 & 75.59 & 25.50 & 182.84 \\
\hline 5 & $\begin{array}{l}\text { Rambutan (Nephelium } \\
\text { lappaceum) }\end{array}$ & 125 & 512.80 & 429.95 & 39.07 & 12.43 & 0.97 & 2.78 \\
\hline 6 & Langsat (Lansium domesticum) & 71 & 732.89 & 391.44 & 96.59 & 30.73 & 10.57 & 77.71 \\
\hline 7 & Jeruk (Citrus sinensis) & 34 & 138.50 & 117.00 & 10.50 & 3.34 & 0.26 & 0.74 \\
\hline 8 & Jambu Air (Syzygium aqueum) & 21 & 143.85 & 84.93 & 17.07 & 5.43 & 1.16 & 5.75 \\
\hline 9 & Petai (Parkia speciosa) & 71 & 559.40 & 320.31 & 84.57 & 26.91 & 8.04 & 44.54 \\
\hline 10 & $\begin{array}{l}\text { Nangka (Artocarpus } \\
\text { heterophyllus) }\end{array}$ & 58 & 422.54 & 256.78 & 64.95 & 20.67 & 5.82 & 30.08 \\
\hline 11 & Sukun (Artocarpus altilis) & 50 & 409.43 & 191.25 & 47.73 & 15.19 & 3.67 & 21.17 \\
\hline 12 & $\begin{array}{l}\text { Mata Kucing (Dimocarpus } \\
\text { longan ssp malesianus var } \\
\text { malesianus) }\end{array}$ & 18 & 194.85 & 116.97 & 14.97 & 4.76 & 1.02 & 7.81 \\
\hline 13 & Gamal (Gliricidia sepium) & 46 & 371.70 & 133.47 & 35.49 & 11.29 & 2.20 & 12.53 \\
\hline 14 & $\begin{array}{l}\text { Jengkol (Archidendron } \\
\text { pauciflorum) }\end{array}$ & 12 & 95.47 & 34.47 & 8.93 & 2.84 & 0.54 & 3.04 \\
\hline 15 & $\begin{array}{l}\text { Lamtoro (Leucaena } \\
\text { leucocophala) }\end{array}$ & 7 & 52.18 & 19.15 & 4.36 & 1.39 & 0.22 & 1.14 \\
\hline 16 & Alpukat (Persea americana) & 7 & 55.76 & 30.49 & 6.18 & 1.97 & 0.45 & 2.51 \\
\hline 17 & Meranti (Shorea $s p$ ) & 7 & 76.08 & 33.04 & 10.31 & 3.28 & 1.24 & 9.54 \\
\hline & T O T A L & 1.154 & & & & & & 797.18 \\
\hline
\end{tabular}

Keterangan $: \mathrm{T}=$ Tinggi Pohon, $\mathrm{TBC}=$ Tinggi Bebas Cabang, $\mathrm{K}=$ Keliling, $\mathrm{D}=\mathrm{Diameter}$, LBDS = Luas Bidang Dasar, $\mathrm{V}=$ Volume 
Pada Tabel 1 dapat dilihat rincian volume total (potensi) tanaman agroforestri responden Desa Mara Satu adalah $797,18 \mathrm{~m}^{3}$ dengan jumlah pohon sebanyak 1.154. Volume tegakan paling besar adalah tanaman Durian (Durio zibethinus) sebesar $270.34 \mathrm{~m}^{3}$ dengan jumlah pohon sebanyak 224 pohon, kemudian diikuti oleh Duku (Lansium domesticum) dengan volume 182,84 dengan jumlah pohon 125 dan volume tegakan yang paling rendah adalah Jeruk (Citrus sinensis) sebesar 0,74 dengan jumlah pohon sebanyak 34 pohon.

Pada praktek agroforestri tumbuh beraneka spesies pohon yang menghasilkan kayu dengan berbagai ukuran dan kualitas yang dapat dipergunakan untuk bahan bakar dan bahan bangunan (timber). Kayu untuk bangunan yang dihasilkan mempunyai nilai ekonomi yang sangat tinggi (Widianto dkk, 2003). Untuk tanaman kehutanan di Desa Mara Satu seperti meranti belum dapat dipanen karena belum masa tebang karena umurnya ratarata masih 10-15 tahun sedangkan umur masa tebang 20-25 tahun.

Berdasarkan fungsi agroforestri yang berkembang di masyarakat Desa Mara Satu memiliki sistem agroforestri yang bersifat Forest Farming. Menurut Hairiah dkk (2003) yang menyatakan bahwa Forest Farming adalah upaya yang digunakan untuk peningkatan produksi lahan hutan, agar tidak melulu produk kayu, tetapi juga mencakup berbagai bahan pangan dan hijauan. Minimal mempunyai fungsi layanan jasa (service function), misalnya pelindung angin, penaung, penyubur tanah, peneduh sehingga dijadikan pusat berkumpulnya keluarga/masyarakat.

\subsubsection{Potensi Hasil Hutan Non Kayu}

Potensi hasil hutan non kayu yang terdapat di dalam sistem agroforestri tradisional yang diterapkan oleh responden petani Desa Mara Satu adalah Potensi tanaman obat-obatan. Sesuai dengan pendapat (Widianto dkk, 2003) bahwa salah satu ciri agroforestri tradisional adalah diversitas komponen salah satunya sebagai bahan baku pengobatan (tanaman obat).

Tanaman untuk obat-obatan merupakan potensi yang besar dan paling banyak dimanfaatkan oleh masyarakat, hal ini terlihat dari beragamnya tanaman obat yang dikembangkan oleh responden petani Desa Mara Satu, tanaman obat tersebut ada yang dijual ada juga yang tidak dijual (dipakai sendiri). Adapun jenis tanaman obat yang dikembangkan di Desa Mara Satu adalah Sirih, Sirih merah, pinang, salam, kumis kucing, mengkudu, jarak, bangle dan lain lain (Tabel 2).

Tabel 2. Jenis Tanaman Obat Pada Lahan Agroforestri di Desa Mara Satu

\begin{tabular}{clcc}
\hline No. & \multicolumn{1}{c}{ Nama Lokal/Daerah } & $\begin{array}{c}\text { Bagian yang } \\
\text { Dimanfaatkan }\end{array}$ & $\begin{array}{c}\text { Nilai Ekonomi } \\
(\text { Rp/tahun })\end{array}$ \\
\hline 1 & Sirih (Piper betle) & Daun & $18,480,000$ \\
2 & Sirih Merah (Piper ornatum) & Daun & $46,080,000$ \\
3 & Pinang (Areca catechu) & Buah & $8,064,000$ \\
4 & Salam (Syzygium polyanthum) & Daun & $6,600,000$ \\
5 & Kumis Kucing (Orthosiphon aristatus) & Bunga & Tidak Dijual \\
\hline
\end{tabular}




\begin{tabular}{clcc}
\hline 6 & Mengkudu (Morinda citrifolia) & Buah & Tidak Dijual \\
7 & Jarak (Ricinus communis) & Daun & Tidak Dijual \\
8 & Bangle (Zingiber cassumunar) & Rimpang & $3,000,000$ \\
9 & Jahe (Zingiber officinale) & Rimpang & $48,750,000$ \\
10 & Kencur (Kaempferia galanga) & Rimpang & $6,750,000$ \\
11 & Kunyit (Curcuma Longa Linn) & Rimpang & $5,200,000$ \\
12 & Jahe Merah (Zingiber officinale Linn. var. rubrum) & Rimpang & $81,600,000$ \\
& & & \\
13 & Kemangi (Ocimum $\times$ citriodorum) & Daun & Tidak Dijual \\
14 & Kembang Sepatu (Hibiscus rosa-sinensis) & Daun & Tidak Dijual \\
& & & \\
15 & Sereh Wangi (Cymbopogon nardus) & Daun & Tidak Dijual \\
16 & Sereh (Cymbopogon citrates) & Daun & Tidak Dijual \\
17 & Tapak Dara (Catharanthus roseus) & Daun & Tidak Dijual \\
18 & Beluntas (Pluchea indica) & Daun & Tidak Dijual \\
19 & Cocor Bebek (Bryophyllum pinnatum) & Daun & Tidak Dijual \\
20 & Lamtoro (Petai Cina) & Biji & - \\
\hline & & & 177.099 .000 \\
\hline
\end{tabular}

Berdasarkan Tabel 2, diperoleh nilai ekonomi dari hasil hutan non kayu dari tanaman obat adalah sebesar Rp. 177.099.000,- dengan potensi yang paling besar adalah jahe merah (Zingiber officinale Linn. var. rubrum) yaitu sebesar Rp. 81.600.000,- yang diikuti oleh Jahe biasa (Zingiber officinale) yaitu sebesar Rp. 48,750,000,- dan Sirih Merah (Piper ornatum) sebesar Rp. 46.080.000,-

Tanaman obat yang tidak dijual ke pasar atau masyarakat sendiri yang memanfaatkannya adalah daun Kumis Kucing (Orthosiphon aristatus), Mengkudu (Morinda citrifolia), Jarak (Ricinus communis), Kemangi (Ocimum $\times$ citriodorum), Kembang Sepatu (Hibiscus rosa-sinensis), Sereh Wangi (Cymbopogon nardus), Sereh (Cymbopogon citrates), Tapak Dara
(Catharanthus roseus), Beluntas (Pluchea indica), Cocor Bebek (Bryophyllum pinnatum), karena beberapa tanaman tersebut banyak terdapat dihutan dan tidak berpotensi untuk dijual. Jahe merah dan Jahe banyak digunakan oleh masyarakat untuk bumbu masak dan untuk minuman penghangat badan. Daun sirih banyak dimanfaatkan oleh masyarakat kerena banyak kegunaannya yaitu mengatasi batuk bronchitis, mengobati luka bakar, mencegah bau mulut, mengatasi mata merah dan gatal-gatal.

\subsection{Nilai Ekonomi Produk Agroforestri}

Sumber daya hutan khususnya pada pola agroforestri mempunyai nilai 
sumberdaya yang sangat tinggi. Untuk menghitung nilai ekonomi produk agroforestri dilakukan pengamatan dilapangan melalui wawancara dan kuisioner kemudian dianalisis secara kuantitatif. Nilai ekonomi jenis-jenis produk agroforestri diperoleh dari perkalian antara total pengambilan per unit per tahun dengan harga hasil hutan per unit per jenis per tahun. Berdasarkan hasil penelitian, beberapa jenis produk agroforestri menghasilkan produk yang dapat dikonsumsi langsung oleh masyarakat. Hal ini sejalan dengan pendapat Nurfatriani (2006) mengatakan bahwa nilai sumber daya hutan sendiri bersumber dari berbagai manfaat yang diperoleh masyarakat. Masyarakat yang menerima manfaat secara langsung akan memiliki persepsi yang positif terhadap nilai sumber daya hutan yang ditunjukkan dengan tingginya nilai sumberdaya hutan tersebut. Nilai ekonomi produk agroforestri dari responden Desa Mara Satu dapat dilihat pada Tabel 3.

Tabel 3. Nilai Ekonomi Produk Agroforestri Responden Desa Mara Satu

\begin{tabular}{|c|c|c|c|c|c|c|}
\hline No. & Produk Agroforestri & Satuan & $\mathrm{TP}$ & Harga & $\mathrm{NE}(\mathrm{Rp} / \mathrm{Thn})$ & $\% \mathrm{NE}$ \\
\hline 1 & Durian & Buah & 115,250 & 5,000 & $576,250,000$ & 17.02 \\
\hline 2 & Elai & Buah & 54,900 & 4,000 & $219,600,000$ & 6.49 \\
\hline 3 & Kuweni & Buah & 52,600 & 800 & $42,080,000$ & 1.24 \\
\hline 4 & Petai & Ikat & 18,150 & 10,000 & $181,500,000$ & 5.36 \\
\hline 5 & Nangka & Buah & 972 & 20,000 & $19,440,000$ & 0.57 \\
\hline 6 & Sukun & Buah & 27,000 & 5,000 & $135,000,000$ & 3.99 \\
\hline 7 & Lamtoro (Petai Cina) & Ikat & 1,320 & 5,000 & $6,600,000$ & 0.19 \\
\hline 8 & Alpukat & $\mathrm{Kg}$ & 420 & 18,000 & $7,560,000$ & 0.22 \\
\hline 9 & Jengkol & $\mathrm{Kg}$ & 3,800 & 10,000 & $38,000,000$ & 1.12 \\
\hline 10 & Jambu Air & $\mathrm{Kg}$ & 19,320 & 20,000 & $386,400,000$ & 11.41 \\
\hline 11 & Duku & $\mathrm{Kg}$ & 36,240 & 12,000 & $434,880,000$ & 12.84 \\
\hline 12 & Langsat & $\mathrm{Kg}$ & 13,840 & 6,000 & $83,040,000$ & 2.45 \\
\hline 13 & Rambutan & $\mathrm{Kg}$ & 17,000 & 8,000 & $136,000,000$ & 4.02 \\
\hline 14 & Jeruk & $\mathrm{Kg}$ & 5,450 & 10,000 & $54,500,000$ & 1.61 \\
\hline 15 & Mata Kucing & $\mathrm{Kg}$ & 6,000 & 8,000 & $48,000,000$ & 1.42 \\
\hline 16 & Pisang & Tandan & 3,015 & 20,000 & $60,300,000$ & 1.78 \\
\hline 17 & Nenas & Buah & 550 & 2,500 & $1,375,000$ & 0.04 \\
\hline 18 & Pepaya & $\mathrm{Kg}$ & & 4,000 & $89,040,000$ & 2.63 \\
\hline
\end{tabular}




\begin{tabular}{|c|c|c|c|c|c|c|}
\hline \multicolumn{7}{|c|}{22,260} \\
\hline 19 & Padi Ladang & $\mathrm{Kg}$ & 22,200 & 14,000 & $310,800,000$ & 9.18 \\
\hline 20 & Kelapa & Buah & 24,700 & 4,000 & $98,800,000$ & 2.92 \\
\hline 21 & Aren (Gula Merah) & $\mathrm{Kg}$ & 576 & 12,000 & $6,912,000$ & 0.20 \\
\hline 22 & Kakao & $\mathrm{Kg}$ & 3,924 & 12,000 & $47,088,000$ & 1.39 \\
\hline 23 & Kopi & $\mathrm{Kg}$ & 4,680 & 15,000 & $70,200,000$ & 2.07 \\
\hline 24 & Sirih & Ikat & 18,480 & 1,000 & $18,480,000$ & 0.55 \\
\hline 25 & Sirih Merah & Ikat & 30,720 & 1,500 & $46,080,000$ & 1.36 \\
\hline 26 & Pinang & $\mathrm{Kg}$ & 672 & 12,000 & $8,064,000$ & 0.24 \\
\hline 27 & Daun Salam & $\mathrm{Kg}$ & 330 & 20,000 & $6,600,000$ & 0.19 \\
\hline 28 & Bangle & $\mathrm{Kg}$ & 300 & 10,000 & $3,000,000$ & 0.09 \\
\hline 29 & Jahe & $\mathrm{Kg}$ & 1,950 & 25,000 & $48,750,000$ & 1.44 \\
\hline 30 & Kencur & $\mathrm{Kg}$ & 675 & 10,000 & $6,750,000$ & 0.20 \\
\hline 31 & Kunyit & $\mathrm{Kg}$ & 520 & 10,000 & $5,200,000$ & 0.15 \\
\hline 32 & Jahe Merah & $\mathrm{Kg}$ & 2,550 & 32,000 & $81,600,000$ & 2.41 \\
\hline 33 & Ternak Sapi & $\mathrm{Kg}$ & 720 & 150,000 & $108,000,000$ & 3.19 \\
\hline & & $\mathrm{T} O \mathrm{O}$ & & & $3,385,889,000$ & 100 \\
\hline
\end{tabular}

Berdasarkan Tabel 3 tersebut dapat dikatakan bahwa komoditi hasil agroforestri yang memberikan nilai ekonomi tertinggi adalah tanaman durian yaitu sebesar Rp. 576.250.000,- per tahun dengan $\% \mathrm{NE}=17.02 \%$, sedangkan komoditi hasil agroforestri yang memberikan nilai ekonomi terendah adalah tanaman nenas yaitu sebesar RP. 1.375.000,- per tahun dengan $\% \mathrm{NE}=$ $0.04 \%$,. Nilai ekonomi dari produk agroforestri yang dihasilkan oleh responden mencerminkan pendapatan responden. Pendapatan merupakan indikator ekonomi petani karena besarnya pendapatan akan menentukan pemenuhan kebutuhan hidupnya (Gautama, 2007). Petani umumnya lebih tertarik melakukan kegiatan yang mampu memberikan pendapatan yang sesuai dan lebih menguntungkan. Pendapatan dari sistem agroforestri umumnya memberikan nilai yang beragam sesuai dengan luasan lahan yang dikelola dan kesesuaian lahan terhadap jenis komoditinya.

Bagi masyarakat Desa Mara Satu untuk tanaman lamtoro (Leucaena leucocophala) selain buahnya memiliki nilai ekonomis sebesar Rp. 6.600.000,per tahun, tapi juga tanaman lamtoro ini tajuknya berfungsi sebagai peneduh atau pelindung, rontokan daunnya sebagai 
penyubur tanah, daun serta ranting mudanya sebagai bahan pakan ternak dan biji buahnya digunakan sebagai obat peluruh air seni (diuretik) dan cacing usus. Sedangkan untuk tanaman gamal (Gliricidia sepium) walaupun tidak memiliki nilai ekonomi, tapi sama halnya seperti lamtoro berguna bagi masyarakat sebagai pohon pelindung dan pakan ternak.

\section{KESIMPULAN}

Kesimpulan dari penelitian ini adalah bahwa Volume total (potensi) tanaman agroforestri responden Desa Mara Satu adalah 797,18 $\mathrm{m}^{3}$ dengan Volume tegakan paling besar adalah tanaman Durian (Durio zibethinus) sebesar $270.34 \mathrm{~m}^{3}$. Potensi tanaman obat Desa Mara Satu memiliki total nilai ekonomi sebesar Rp. 177.099.000,- per tahun dengan potensi yang paling besar adalah jahe merah (Zingiber officinale Linn. var. rubrum) yaitu sebesar Rp. 81.600.000,- per tahun. Total nilai ekonomi produk tanaman agroforestri dari 37 responden petani Desa Mara Satu adalah sebesar Rp. 3.385.889.000,- per tahun.

\section{UCAPAN TERIMA KASIH}

Kami ucapkan terimakasih kepada Rektor Universitas Kaltara dan Dekan Fakultas Pertanian Universitas Kaltara atas dukungannya, kepada Fakultas Kehutanan Universitas Mulawarman atas kerjasamanya dan ucapan terimakasih kepada masyarakat Desa Mara Satu yang telah memfasilitasi penelitian kami.

\section{DAFTAR PUSTAKA}

Amirin, T. (2011). Populasi Dan Sampel Penelitian 4 : Ukuran Sampel Rumus Slovin. Jakarta : Erlangga.

Gautama, I. (2007). Studi Sosial Ekonomi Masyarakat pada Sistem Agroforestri di Desa Lasiwala Kabupaten Sidrap. Jurnal Hutan Masyarakat, Vol 2 No. 3 Hal. 319328

Hairiah , K., M. A., Sardjono, dan S. Sabarnurdin. (2003). Pengantar Agroforestri. World Agroforestry Centre (ICRAF), Bogor. 
Nair. (1993). An Intoduction to Agroforestry. Kluwer Academic Publisher. Dordrecht, The Netherlands.

Nurfatriani, F. (2006). Konsep Nilai EKonomi Total dan Metode Penilaian Sumber Daya Hutan. Jurnal Penelitian Sosial dan Ekonomi Kehutanan Jilid 3. Forestry Research, Development and Innovation Agency, Jakarta
Widianto, Kurniatun Hairiah, Didik Suharjito dan Mustofa Agung Sardjono. (2003). Fungsi dan Peran Agroforestri. World Agroforestry Centre (ICRAF), Bogor. 49 hlm. 